\title{
The Relationship Between Motivation and Worker's Productivity in Civil Registration and Population Department, Asahan Regency, Indonesia
}

\author{
Supiah Ningsih \\ Lecturer in Muhammadiyah Economic Higher Education, Asahan (STIEMA), Indonesia
}

\begin{abstract}
Human resources as labor or employees play an important role in improving productivity and achievement of predetermined objectives. Efforts to mobilize labor are an important task for agencies. In this case the agency should be able to do coaching on employees so that they want to perform work activities effectively and efficiently. By conducting coaching on employees, will be obtained by qualified, competent, reliable, have high morale to achieve a goal that leads to work performance. The result of data analysis with multiple linear regression analysis method $Y=5.567+0,105 X 1+0,967 X 2+0,450 X 3+1,078 X 4+0,164 X 5+e$, it means that every improvement of motivation variable consist of $X 1, X 2, X 3, X 4, X 5$ for one unit then it will also increase the productivity at the Department of Population and Civil Registration Kab. Asahan of 0.105, 0.967, 0.450, 1.078, and 0.164 units.
\end{abstract}

Keywords: motivation; productivity; economy; workers

\section{INTRODUCTION}

The era of globalization is characterized by rapid development in all fields. The globalization that has swept the world has influenced the development of various sectors of activities in Indonesia. Competition in a very tight working world exposes organizations to strong efficiency and competitiveness. To improve efficiency, among others required Human Resources (HR) quality. The most important resource in an organization is the human resources, the people who provide the energy, talents, creativity and their efforts to the organization for an organization 
to survive its existence.. One indicator that can be used to measure organizational and individual achievement is performance through the influence of motivation. Motivation is a very important factor for the development of agencies, both now and in the future. Motivation is an impulse that is done so that a person can do a job or action in accordance with the desired to achieve the goals set. According to Handoko (2003: 251) motivation is very important because motivation is an activity that leads, distributes and maintains human behavior to perform certain activities to achieve its goals. Effort is a provision arising from the motivation that exists within a person, while the ability to reflect the skills, information, talents possessed by the individual. Motivation can also be defined as a force or energy that drives a person's behavior to move, both intrinsically and extrinsically. The intrinsic condition in which this power affects the individual by determining the various views, which are thought to lead behavior in a particular situation . Interest theory is seen as a form of internal motivation because the desires and interests of an individual are in the self for the achievement of an achievement. Good motivation and wisdom implanted superiors can affect the level of welfare agencies and employees. Where motivation serve as a benchmark for achieving the goals of agencies and employees. Managers who can see motivation as a system that includes individual characteristics, occupations, work situations, and understand the relationship between intensive, motivation, and productivity they will be able to estimate employee behavior. The impact of motivation that works well will result in good work performance. An employee who works at an agency expects something from that agency. Something an employee expects is not just a wage or salary, but also other matters that can provide assurance to the employee about the continuity of the job and his career. Achieving the expectation of employees will increase employee productivity. According Siagian (2007: 57) productivity as a mental attitude that always has the view that the quality of life today must be better than yesterday and tomorrow better than today. Siagian (2007: 114), states that there are many factors that affect the productivity of work, both related to the workforce and related to the environment and government policy as a whole. 


\section{REVIEW OF LITERATURE}

\subsection{Motivation}

Motivation is an encouragement that makes people want to work or act in a certain way. Speaking of motivational matters, what is discussed is human needs. The relationship between motivation and need is two things that cannot be separated from each other.

Some understanding of motivation, among others:

a. According to Hasibuan (2000: 143) motivation is the driving force that creates the excitement of a person to be able and willing to cooperate, work effectively and integrated with his efforts to achieve satisfaction.

b. According to Mathis L. Robert and Jakson H.John (2001: 89) motivation is a desire within a person that causes the person to take action.

c. According to Winardi (2000: 6) motivation is a potential power that exists in a person who can be developed alone or developed by a number of outside forces which in essence ranging from monetary rewards and non-monetary rewards that can affect the results of work positively or negatively which depends on the conditions faced by the person concerned.

d. According to Nawawi (2000: 351) the word motivation (motivation) has a basic word motif, which means the drive cause or basis someone to do something. Thus motivation means a condition that encourages or becomes the cause of a person doing an act or activity that takes place consciously.

Motivation can also be defined as a force or energy that drives one's behavior to activity, which is influenced intrinsically (intrinsically) and extrinsically (from the outside).

According Siagian (1995: 290), motivation factors are things that drive the achievement of intrinsic nature, which comes from within a person, while the hygiene factors are factors that are extrinsic, which means sourced from outside a person. Motivation factor is a motivator factor that concerns a person's psychological needs that is perfect feeling in doing the job. This motivational factor is related to rewards towards the person who is directly related to the job. This motivation factor can be regarded as intrinsic factor derived from within a person (Hasibuan, 2008: 110), which include: 
a. Achievement (Achievement)

b. Recognition (Recognition)

c. The work itself (The work itself)

d. Responsibility (Responsibility)

e. Development of individual potential (Advancement)

An employee who works at an agency expects something from that agency. Something an employee expects is not just a wage or salary, but also other matters that can provide assurance to the employee about the continuity of the job and his career. Achieving the expectation of employees will increase employee productivity. The International Labor Organization (ILO) reveals that, more simply, the purpose of productivity is the computation of arithmetic between the amount produced and the amount of each source used during production (Hasibuan, 2003: 126-127).

\section{METHODS OF THE RESEARCH}

\subsection{Research Approach}

According to how to obtain the data used in this research form (Supranto, 2000: 10):

a. Primary data: Primary data is data obtained directly from the source by way of visiting the Office of Population and Civil Registration Asahan Regency.

b. Secondary Data: Secondary data is data collected by researchers themselves, for example from reading books, the data obtained from this literature research is needed as a basic comparison of data obtained from the field is secondary data.

\subsection{Operational Definition of Variables}

To explain the variables that have been defined then required the operational definition of each variable as an effort of understanding in research. Motivation (X), consisting of:

a. Variable X1 is Achievement, self desire to do the job better so as to produce achievement that lift self-esteem compared with other person.

b. Variable X2 is Recognition, the desire to always get the attention and trust from superiors that he is more capable than colleagues. 
c. Variable X3 is the Work itself, where work is used as a fun activity so that new things in the work are no longer considered as a burden.

d. Variable X4 that is Responsibility, every action in the work activities can be accounted for good and bad.

e. Variable X5 is the development of individual potential, the work is considered as an opportunity to grow, so as to develop the potential by itself to always be the best productivity $(\mathrm{Y})$, as a mental attitude that always has the view that the quality of life today must be better than yesterday and tomorrow is better than today.

\section{DISCUSSION}

\subsection{Test Validity and Reliability}

Validity and reliability test in this research is done outside the selected respondents or outside the research sample that is as many as 30 people. Validity and reliability test in this study aims to determine whether the questionnaire is feasible or not feasible as an instrument used to collect information from research respondents. Validity and reliability test is done by comparing between $r$ table and $r$ count. If $r$ arithmetic $>$ from $r$ table it can be concluded that the questionnaire is valid, otherwise when $\mathrm{r}$ arithmetic $<\mathrm{r}$ table then the questionnaire is not valid. Determining whether or not reliable questionnaire can be known when $r$ alpha $>r$ table then the questionnaire reliable, otherwise if $\mathrm{r}$ alpha $<\mathrm{r}$ table then the questionnaire is not reliable. Result of validity and reliability test based on writer's data can be seen in table 1 as follows:

Table 1

\section{Item-Total Statistics}

\begin{tabular}{|l|lr|l|l|l|l|}
\hline & & Scale & & & Cronbach's \\
& Scale & Mean & Variance if & Corrected & Squared & Alphar if \\
& if & Item & Item & Item-Total & Multiple & Item \\
\hline
\end{tabular}




\begin{tabular}{|l|l|l|l|l|l|}
\hline q1 & 53.00 & 75.172 & .597 & $\cdot$ & .935 \\
q2 & 53.30 & 75.803 & .580 &. & .937 \\
q3 & 54.13 & 68.740 & .907 &. & .927 \\
q4 & 54.03 & 71.068 & .782 &. & .930 \\
q5 & 54.30 & 63.597 & .777 &. & .931 \\
q6 & 53.00 & 75.448 & .582 &. & .936 \\
q7 & 53.17 & 76.282 & .515 &. & .938 \\
q8 & 54.00 & 68.276 & .813 &. & .928 \\
q9 & 53.93 & 75.237 & .643 &. & .935 \\
q10 & 54.13 & 75.292 & .534 &. & .936 \\
q11 & 53.70 & 64.769 & .848 &. & .927 \\
q12 & 53.67 & 71.402 & .812 & .930 \\
q13 & 54.57 & 61.082 & .815 & .83 \\
q14 & 54.40 & 61.834 & .867 & .781 & .927 \\
q15 & 54.47 & 68.947 & .929 & .9 \\
\hline
\end{tabular}

Source: Primary data, 2017. (processed)

\subsection{Interpretation}

a. Scale Mean if Deleted Item specifies the total average value if the variable is deleted. For example, if the first questionnaire is deleted then the average total is worth 53.00, if the second questionnaire is deleted then the total average is worth 53.30 and so on.

b. Scale Variance if Deleted Item describes the magnitude of the total variant if the variable is deleted. The magnitude of the total variant if the first questionnaire is deleted is 75.172 , if the second questionnaire is deleted is 75.803 and so on.

c. Corrected Item-Total Correlation is the correlation between the total score of the questionnaire that can be used to test the validity of the instrument. The value in the Corrected Item-Total Correlation column is the value of $\mathrm{r}$ arithmetic which will be compared with $r$ table to know the validity of each questionnaire. The author creates a new table, this is meant to show the comparison between $r$ table and $r$ count as follows: 
Table 2

Validity test

\begin{tabular}{|l|ll|l|l|}
\hline & \multicolumn{2}{|l|}{$\mathrm{r}_{\text {hitung tiap pertanyaan }}$} & & \\
& $\begin{array}{l}\text { Corrected Item-Total } \\
\text { Correlation }\end{array}$ & $\mathrm{r}_{\text {tabel }}$ & Validitas \\
\hline $\mathrm{q} 1$ & .597 & 0,514 & Valid \\
$\mathrm{q} 2$ & .580 & 0,514 & Valid \\
$\mathrm{q} 3$ & .907 & 0,514 & Valid \\
$\mathrm{q} 4$ & .782 & 0,514 & Valid \\
$\mathrm{q} 5$ & .777 & 0,514 & Valid \\
$\mathrm{q} 6$ & .582 & 0,514 & Valid \\
$\mathrm{q} 7$ & .515 & 0,514 & Valid \\
$\mathrm{q} 8$ & .813 & 0,514 & Valid \\
$\mathrm{q} 9$ & .643 & 0,514 & Valid \\
q10 & .534 & 0,514 & Valid \\
q11 & .848 & 0,514 & Valid \\
q12 & .812 & 0,514 & Valid \\
q13 & .815 & $.0,514$ & Valid \\
q14 & .867 & 0,514 & Valid \\
q15 & .781 & 0,514 & Valid \\
\hline
\end{tabular}

Source: Primary data, 2017. (processed)

Conditions for decision making:

1. If $r$ arithmetic $>r$ table then the questionnaire is valid

2 . If $r$ arithmetic $<r$ table then the questionnaire is not valid

3. $\mathrm{R}$ value of table is obtained from $\mathrm{df}=\mathrm{k}-2$ with $\alpha=0,05$. Then $\mathrm{df}=15-2=13$. So $\mathrm{r}$ table $(0,05$; $13)$ is 0,514 .

Table 3 shows that $r$ arithmetic $>r$ table so that based on the data it is concluded that all questions on the questionnaire are valid and deserve to be used as research instrument. After all 
questionnaires declared valid, then the next test is to test the reliability questionnaire that can be seen in table 4.3 as follows:

Table 3

Reliability Statistics

\begin{tabular}{|l|l|}
\hline $\begin{array}{l}\text { Cronbach's } \\
\text { Alpha }\end{array}$ & N of Items \\
\hline .936 & 15 \\
\hline
\end{tabular}

Source: Primary data, 2017 (processed)

Terms of decision making:

a. If $\mathrm{r}$ alpha> $\mathrm{r}$ table then the questionnaire declared reliable.

b. If $\mathrm{r}$ alpha $<\mathrm{r}$ table then the questionnaire declared not reliable

Table 3 shows that $r$ alpha is 0.936 while $r$ table value is 0,514 . This means that $r$ alpha $>r$ table is 0.936>0.514. Based on the data it is concluded that the questionnaire is reliable and feasible to be used as a research instrument.

Descriptive analysis is a way of formulating and interpreting the existing data so as to provide a clear picture of the data under study. Descriptive analysis in this research is a description or explanation of the primary data collection in the form of questionnaires that have been filled by the respondents as many as 30 people who contain questions about the influence of motivation (X) on productivity (Y) on the Department of Population and Civil Registration Kab. Asahan. Here is described the descriptive analysis in this study are:

\section{a. Characteristics of respondents by gender}

\section{Table 4}

Characteristics of Respondents by gender

\begin{tabular}{|l|l|l|}
\hline Gender & total & Percentage (\%) \\
\hline Man & 19 & $63,33 \%$ \\
\hline Woman & 11 & $36,67 \%$ \\
\hline Total & 30 people & $100 \%$ \\
\hline
\end{tabular}

Source: Primary data. (processed) 
Table 4 can be seen that the number of female and male respondents who reside in the Department of Population and Civil Registration Kab. Asahan showed no significant difference. Number of male respondents in the Department of Population and Civil Registration of Kab. Asahan as many as 19 people $(63.33 \%)$ while female respondents as many as 11 people $(36.67 \%)$.

\section{b. Characteristics of respondents by age}

Table 5

Characteristics of Respondents by Age

\begin{tabular}{|l|l|l|}
\hline Age & Total & Percentage (\%) \\
\hline $21-26$ year & 8 & $26,67 \%$ \\
\hline $27-32$ year & 12 & $40 \%$ \\
\hline $33-38$ year & 6 & $20 \%$ \\
\hline $39-45$ year & 4 & $13,33 \%$ \\
\hline Total & 30 people & $100 \%$ \\
\hline
\end{tabular}

Source: Primary data. (processed)

Table 5 shows that most respondents in the Department of Population and Civil Registration of Kab. Asahan were 27-32 years old respondents (12\%), followed by respondents aged 21-26 years, 8 people (26.67\%), and respondents aged 33-38 years as many as 6 people (20 $\%)$, and the last is respondents aged $39-45$ as many as 4 people (13.33\%).

\section{c. Characteristics of respondents by education level}

\section{Table 6}

\section{Characteristics of Respondents by Level of Education}

\begin{tabular}{|l|l|l|}
\hline $\begin{array}{l}\text { Level of } \\
\text { education }\end{array}$ & Total & Percentage (\%) \\
\hline SMU & 5 & $16,67 \%$ \\
\hline D3 & 7 & $23,33 \%$ \\
\hline S1 & 16 & $53,33 \%$ \\
\hline S2 & 2 & $6,67 \%$ \\
\hline
\end{tabular}




\section{Source: Primary data. (processed)}

Table 6 shows that respondents based on educational level are dominated by respondents who have S1 degree as much as 16 people $(53.33 \%)$, followed by respondents who have D3 education of 7 people (23.33\%), and who have the smallest percentage are respondents who have high school education as many as 5 people $(16.67 \%)$, and followed by respondents who educated S2 as much as 2 people (6.67\%).

\section{d. Characteristics of respondents by years of service}

Table 7

\section{Characteristics of Respondents Based on Work Period}

\begin{tabular}{|l|l|l|}
\hline Working period & Total & Percentage $(\%)$ \\
\hline $1-3$ year & 6 & $20 \%$ \\
\hline $4-6$ year & 16 & $53,34 \%$ \\
\hline $7-10$ year & 4 & $13,33 \%$ \\
\hline $11-14$ year & 4 & $13,33 \%$ \\
\hline Total & 30 people & $100 \%$ \\
\hline
\end{tabular}

\section{Source: Primary data. (processed)}

Table 8

Motivation Variable (X)

\begin{tabular}{|c|c|c|c|c|c|c|c|c|c|c|c|c|}
\hline \multirow[t]{2}{*}{ Statement } & \multicolumn{2}{|c|}{ SS } & \multicolumn{2}{|c|}{$\mathbf{S}$} & \multicolumn{2}{|c|}{ KS } & \multicolumn{2}{|c|}{ TS } & \multicolumn{2}{|c|}{ STS } & \multicolumn{2}{|c|}{ Total } \\
\hline & $\mathbf{F}$ & $\%$ & $\mathbf{F}$ & $\%$ & $\mathbf{F}$ & $\%$ & $\mathbf{F}$ & $\%$ & $\mathbf{F}$ & $\%$ & $\mathbf{F}$ & $\%$ \\
\hline \multicolumn{13}{|c|}{ Achievement $X_{1}$} \\
\hline 1 & 14 & 46,67 & 14 & 46,67 & 2 & 6,66 & 0 & 0 & 0 & 0 & 30 & $100 \%$ \\
\hline 2 & 14 & 46,67 & 12 & 40,00 & 4 & 13,33 & 0 & 0 & 0 & 0 & 30 & $100 \%$ \\
\hline \multicolumn{13}{|c|}{ Achievement $X_{2}$} \\
\hline 3 & 15 & 50,00 & 9 & 30,00 & 6 & 20,00 & 0 & 0 & 0 & 0 & 30 & $100 \%$ \\
\hline 4 & 10 & 33,33 & 18 & 60,00 & 2 & 6,67 & 0 & 0 & 0 & 0 & 30 & $100 \%$ \\
\hline \multicolumn{13}{|c|}{ Work Itself $\mathbf{X}_{3}$} \\
\hline 5 & 16 & 53,33 & 10 & 33,33 & 4 & 13,34 & 0 & 0 & 0 & 0 & 30 & $100 \%$ \\
\hline
\end{tabular}




\begin{tabular}{|c|c|c|c|c|c|c|c|c|c|c|c|c|}
\hline 6 & 16 & 53,33 & 10 & 33,33 & 4 & 13,34 & 0 & 0 & 0 & 0 & 30 & $100 \%$ \\
\hline \multicolumn{10}{|c|}{ Responsible $\mathbf{X}_{\mathbf{4}}$} \\
\hline 7 & 13 & 43,33 & 12 & 40,00 & 5 & 16,67 & 0 & 0 & 0 & 0 & 30 & $100 \%$ \\
\hline 8 & 10 & 33,33 & 15 & 50,00 & 5 & 16,67 & 0 & 0 & 0 & 0 & 30 & $100 \%$ \\
\hline \multicolumn{10}{|c|}{ Development of Individual Potential $\mathbf{X}_{5}$} \\
\hline 9 & 9 & 30,00 & 18 & 60,00 & 3 & 10,00 & 0 & 0 & 0 & 0 & 30 & $100 \%$ \\
\hline 10 & 13 & 43,33 & 14 & 46,67 & 3 & 10,00 & 0 & 0 & 0 & 0 & 30 & $100 \%$ \\
\hline
\end{tabular}

\section{Source: Primary data (processed)}

Table 4.9

Variable Productivity (Y)

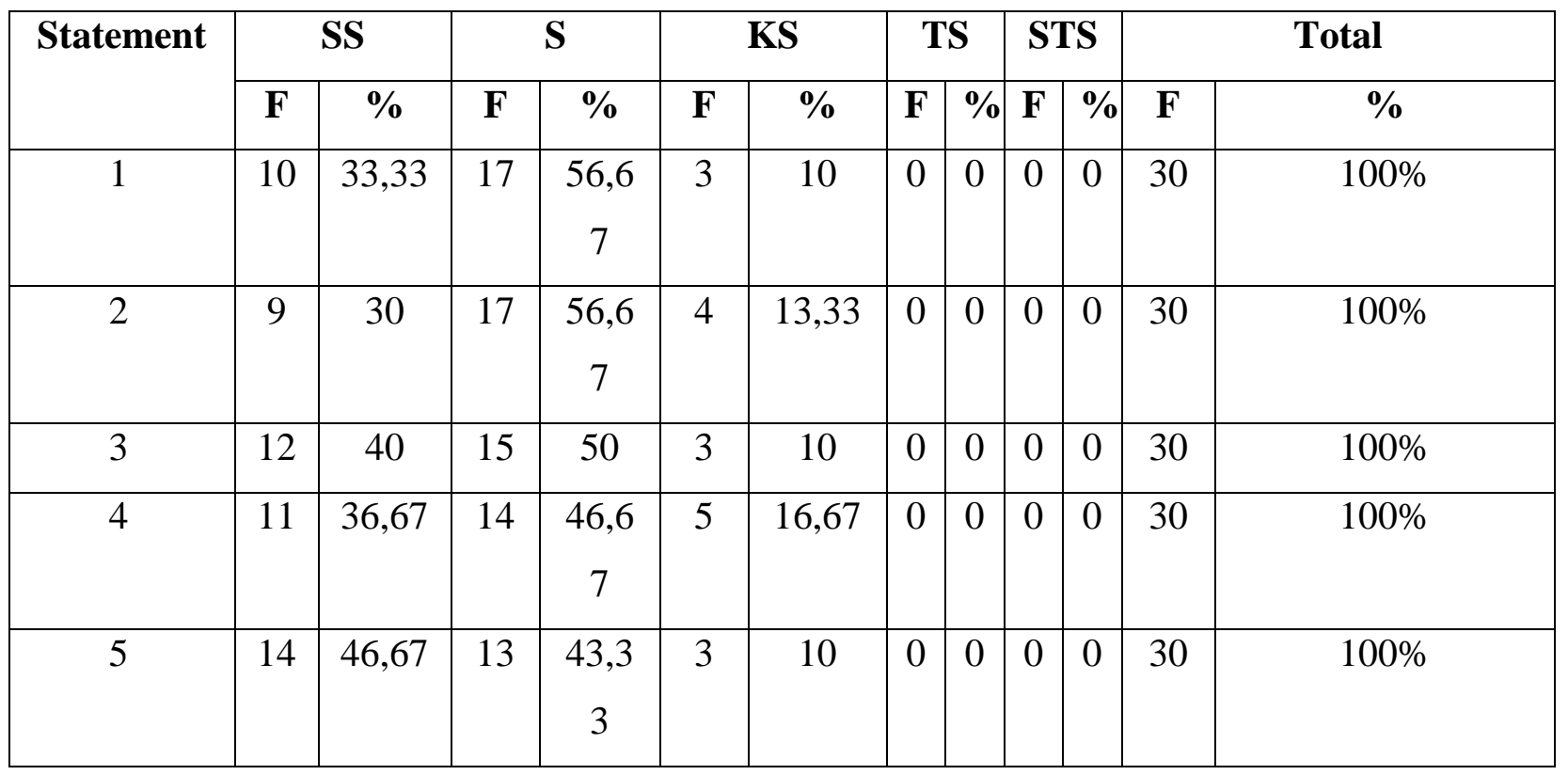

Source: Primary data (processed)

\section{CONCLUSION}

The results of research conducted by the authors show that the motivation (X) has a significant effect on productivity (Y). This is obtained from the analysis and discussion of the author, which shows the data as follows: 
a. The result of data analysis with multiple linear regression analysis method $\mathrm{Y}=5.567+$ $0,105 \mathrm{X} 1+0,967 \mathrm{X} 2+0,450 \mathrm{X} 3+1,078 \mathrm{X} 4+0,164 \mathrm{X} 5+\mathrm{e}$, it means that every improvement of motivation variable consist of $\mathrm{X} 1, \mathrm{X} 2, \mathrm{X} 3, \mathrm{X} 4, \mathrm{X} 5$ for one unit then it will also increase the productivity at the Department of Population and Civil Registration in Asahan of 0.105, 0.967, 0.450, 1.078, and 0.164 units.

b. The result of hypothesis testing through $t$ test (partial test) shows that the value of $t$ count $>t$ table, where the $\mathrm{t}$ count value of 5.170 while the value of $\mathrm{t}$ table of 2.23 , so that Ho hypothesis is rejected and $\mathrm{Ha}$ accepted. Based on the data, it can be concluded that the motivation variable consisting of $(\mathrm{X} 1, \mathrm{X} 2, \mathrm{X} 3, \mathrm{X} 4, \mathrm{X} 5)$ has a significant effect on the productivity variable (Y) on the Department of Population and Civil Registration in Asahan Regency.

c. The result of hypothesis testing through F-test shows that the value of $\mathrm{F}$ count $>\mathrm{F}$ table, where the value of $\mathrm{F}$ count is 6,081 , while the $\mathrm{F}$ table value is 2,16 or $6,081>2,16$. So the hypothesis Ho rejected and $\mathrm{Ha}$ accepted. Based on the data, it is concluded that the motivation variable consisting of the need for achievement (X1), Recognition Needs (X2), the Need for Working Itself (X3), the Need for Responsibility (X4), the Need for Development of individual potency (X5) to the productivity variable (Y) on the Department of Population and Civil Registration of in Asahan.

\section{REFERENCES}

Anwar, A.A. Prabu Mangkunegara. 2000. “MSDM Instansi”, Penerbit PT. Remeja Rosdakarya, Bandung.

Edhi, Arep, Ishak dan Hendri Tanjung. 2006. "Manajemen Motivasi”, Penerbit Gramedia Widiasarana Indonesia, Jakarta.

Handoko T. Hani. 2003. "Manajemen Personalia dan Sumber Daya Manusia”, Edisi II, Cetakan Keempat belas, Penerbit BPFE, Yogyakarta.

Hasibuan, H. Malayu. 2000. "Manajemen Sumber Daya Manusia”, Edisi Revisi, Penerbit Bumi Aksara, Jakarta. 
Hasibuan, H. malayu. 2008. "Organisasi dan Motivasi”, Cetakan Keenam, Penerbit Bumi Aksara, Jakarta.

Harianja, Marihot Tua Efendi. 2002. “Manajemen Sumber Daya Manusia”, Penerbit PT. Gramedia Widiasarana Indonesia, Jakarta.

Mathis L.Robert dan Jakson H.John 2001. "Manajemen SDM", PT. Remaja Rosdakarya, Bandung.

Notoadmojo, Soekidjo. 2003. "Pengembangan SDM", Penerbit PT. Rineka Cipta, Cetakan Ketiga, Jakarta.

Nawawi, Hadari. 2000. “Manajemen Sumber Daya Manusia untuk Bisnis yang Kompetitif”, Gadjah Mada University Press, Yogyakarta.

Rivai, Veithzal. 2004. “Manajemen Sumber Daya Manusia untuk Instansi”, Penerbit PT. Rajagrafindo Persada, Jakarta.

Schuler 2001. “Manajemen”, Penerbit Rineka Cipta, Jakarta.

Sinungan, 2003. "Dasar-dasar Manajemen”, Cetakan kelima, Ghalia Indonesia, Jakarta.

Siagian. P Sondang. 2007. "Manajemen Sumber Daya Manusia”, Edisi Revisi, Penerbit Bumi Aksara, Jakarta.

Sugiono,2008. "Metode Penelitian Bisnis", Cetakan ke Sebelas, Penerbit CV. Alfabeta, Bandung.

Winardi, J. 2001. "Motivasi dan Pemotivasian dalam Manajemen”, PT. Grafindo Persada, Jakarta. 